\title{
Evaluasi Kematangan Sistem Informasi Untuk Keselarasan Bisnis pada Perusahaan Manufaktur
}

\author{
http://dx.doi.org/10.28932/jutisi.v7i2.3665 \\ Riwayat Artikel \\ Received: 8 Juni 2021 | Final Revision: 6 Juli 2021 | Accepted: 7 Juli 2021

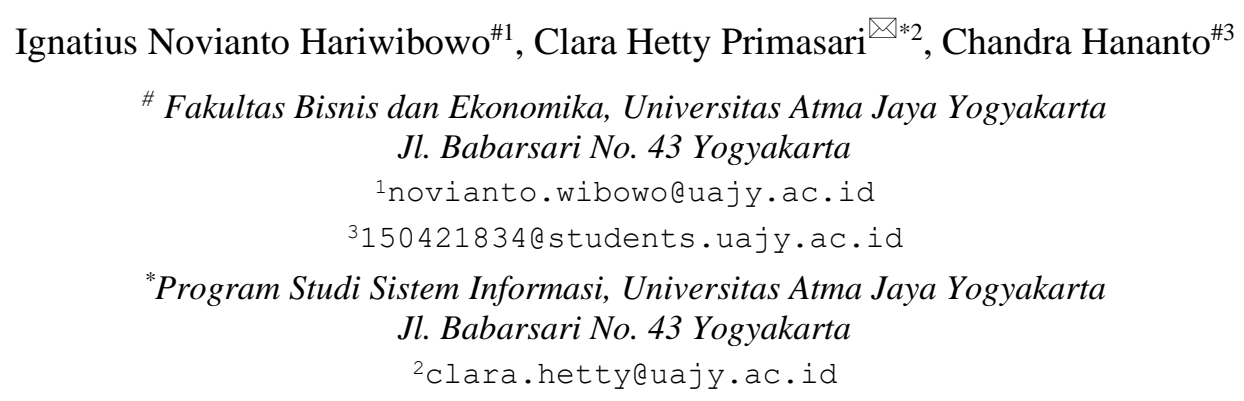

\begin{abstract}
This study aims to evaluate the alignment of the application of information technology (IT) with the company's business practices. This study uses COBIT 4.1. to assess the maturity of technology adoption and to explore factors that hinder the alignment of IT implementation with the business. The maturity level of technology application describes IT management in the company's overall business activities. The higher the maturity level, the clearer and more structured the role of IT and business will be. This research uses a case study method at PT. SAE (in Central Java Province). The result of this research is that PT. SAE has reached the defined process level. At this stage, the company already has standard IT management procedures, but not all business activities and not yet detailed. This problem is due to lack of strategic support from top management to achieve business goals with the help of IT. Therefore, the company needs to improve the function and role of the head of the IT department at PT. SAE
\end{abstract}

Keywords— Business Strategy; COBIT 4.1; IT Business Alignment; Maturity Level

\section{PENDAHULUAN}

Dalam usaha mengembangkan bisnis, penerapan teknologi informasi (TI) memiliki peran yang penting. TI adalah alat untuk mencapai peningkatan efektifitas dan efisien kinerja perusahaan, dan untuk mendapatkan keunggulan yang kompetitif [1]. Untuk mencapai kondisi tersebut, implementasi tata kelola TI perlu memiliki konsep yang jelas dan bersifat strategis untuk mencapai kinerja bisnis perusahaan baik internal atau eksternal [2]. Tata kelola TI memiliki manfaat dalam mengarahkan investasi teknologi untuk fokus pada keselarasan strategis, pencapaian nilai, pengelolaan sumber daya, dan pengukuran kinerja [3].

Dalam pengembangan manajemen/pengelolaan TI terkait dengan keselarasan bisnis, metode atau kerangka kerja COBIT adalah standar baku internasional yang diterapkan untuk menilai tingkat kematangan (maturity level) tata kelola TI. Dengan menggunakan COBIT akan diketahui tingkat pengelolaan teknologi informasi untuk mendukung bisnis perusahaan [3]. Metode ini akan dapat memberikan rekomendasi alat ukur tata kelola teknologi informasi serta langkah yang perlu untuk diadopsi dalam pengelolaan TI.

Penerapan konsep COBIT telah memberikan nilai positif bagi organisasi. Hal ini ditunjukkan dari beberapa penelitian terdahulu tentang penerapan COBIT. Penerapan COBIT untuk evaluasi pengelolaan teknologi informasi telah dijelaskan oleh [4], [5], dan [6]. Penelitian tersebut menjelaskan tingkat kematangan yang berbeda-beda pada organisasi yang berbeda. Hasil penelitian tersebut menunjukkan masih adanya gap antara praktik pengelolaan teknologi informasi yang sesungguhnya dengan yang diharapkan, dengan masih terdapat kelemahan di masing-masing indikator atau domainnya. Hasil penelitian terdahulu menunjukkan bahwa hasil tingkat kematangan pada COBIT 4.1 sangat bermanfaat bagi manajemen dan pengguna teknologi informasi di perusahaan untuk meningkatkan pengendalian dan pengawasan di proses teknologi informasi, dan juga berguna untuk memberikan arahan atau rekomendasi yang berorientasi pada bisnis untuk meningkatkan efektivitas perusahaan dan menjalankan strategi perusahaan [7]. Dengan adanya pengendalian dan rekomendasi dari COBIT 4.1 membuat investasi teknologi informasi 
yang dikeluarkan sebanding. Maka dari itu perusahaan dapat menerapkan pengelolaan TI dengan tepat, yang dimulai dari tahap perencanaan hingga tahap implementasi, dan mengacu pada standar yang sudah ditetapkan agar manfaat investasi teknologi informasi pada perusahaan dapat memberikan dampak yang positif yaitu perusahaan memiliki keunggulan kompetitif yang baik.

Sebagai perusahaan manufaktur yang memproduksi kabel audio dan video terbesar di Indonesia, berlokasi di Provinsi Jawa Tengah, PT. SAE merupakan perusahaan yang telah menerapkan TI untuk mendukung tercapainya tujuan bisnis. Upaya penerapan TI tersebut dilakukan agar mendukung produktivitas perusahaan dengan mencapai proses kegiatan perusahaan yang lebih baik dan efisien. Dalam usaha mencapai produktivitas sistem, beberapa kendala yang masih dihadapi yaitu strategi teknologi informasi dan strategi bisnis belum dapat sejalan. Masalah ini disebabkan karena belum dilakukannya strategi evaluasi konsep TI perusahaan secara menyeluruh dan belum ditetapkannya strategi berkelanjutan tiap-tiap tahunnya. Penerapan infrastruktur TI pada PT. SAE yang merupakan pendukung dalam kinerja di perusahaan perlu di tata dengan tepat untuk mencapai kinerja bisnis yang optimal [7].

Untuk mengatasi masalah tersebut, perlu adanya pengukuran atau penilaian dari pengelolaan TI. Framework COBIT 4.1 dapat menjadi konsep yang tepat untuk mengevaluasi sejauh mana tata kelola TI pada PT. SAE. Melalui penilaian tingkat kematangan pengelolaan TI, keselarasan strategi bisnis dengan pengembangan TI dapat diukur [8]. Hasil penelitian akan mengevaluasi penerapan TI dan memberikan rekomendasi untuk peningkatan kinerja dari teknologi informasi tersebut. Nilai dan rekomendasi akan menjadi masukan dan panduan bagi manajemen perusahaan dalam pengelolaan TI di masa datang.

\section{MEtode Penelitian}

\section{A. Kajian Literatur}

\section{1) IT Governance (Tata Kelola Teknologi Informasi)}

Menurut IT Governance Institute (2007), pengelolaan TI membutuhkan peran manajemen eksekutif yang berada di dalam struktur perusahaan perusahaan untuk memastikan penerapan TI perusahaan telah mendorong pencapaian strategi dan sasaran bisnis perusahaan [3]. Ratih et al. [9] menjelaskan bahwa pengelolaan TI dalam perusahaan perlu memastikan efektivitas dan efisiensi proses bisnis, yang dilakukan melalui struktur bisnis organisasi untuk pencapaian strategi perusahaan. Konsep pengelolaan TI mengarahkan organisasi untuk mencapai tuntutan kompetisi bisnis pada saat ini dan masa depan. Pengelolaan TI menetapkan distribusi hak dan wewenang dalam pengambilan keputusan TI, serta prosedur untuk membuat dan memantau keputusan strategis mengenai TI [10].

Menurut IT Governance Institute (2003), keberadaan teknologi sekarang sangat terkait pada aktivitas di berbagai bidang dalam perusahaan [11]. Dalam hal ini, pimpinan puncak harus memberikan perhatian terhadap pengelolaan teknologi informasi. Kebutuhan perusahaan terhadap penerapan TI dan peran penting TI bagi tercapainya strategi bisnis perusahaan perlu dirumuskan oleh manajemen puncak. Alasan terpenting pengelolaan teknologi informasi perlu diterapkan, menurut IT Governance Institute (2003), adalah terjadinya ekspektasi dan realita sering kali tidak sesuai.

\section{2) Fokus Area Pengelolaan Teknologi Informasi}

IT Governance Institute (2007) [3] menjelaskan bahwa dalam pengelolaan teknologi informasi pada perusahaan, tata kelola TI memiliki area fokus yang menjelaskan topik apa saja yang perlu ditangani oleh manajemen perusahaan mereka. Fokus area pengelolaan teknologi informasi yaitu:

1. Strategic alignment (keselarasan strategis) adalah fokus pada kaitan strategi bisnis dengan teknologi informasi; yang meliputi pendefinisian, pemeliharaan dan validasi proposisi nilai teknologi informasi; dan penyelarasan operasi teknologi informasi dengan operasional perusahaan.

2. Value delivery (pendistribusian nilai) adalah fokus pada pelaksanaan nilai pada semua siklus pengiriman. Fokus ini adalah untuk menentukan bahwa TI memberikan manfaat bagi strategi perusahaan, optimalisasi biaya, dan nilai dasar penerapan teknologi informasi.

3. Resource management (manajemen sumber daya) adalah fokus terhadap optimalisasi investasi dan pengelolaan yang tepat. Fokus ini juga meliputi sumber daya TI, yang terdiri dari: aplikasi, infrastruktur, informasi, dan pengguna.

4. Risk management (manajemen risiko) adalah fokus terhadap pemahaman adanya risiko oleh manajemen senior, yang meliputi: pemahaman yang jelas tentang perusahaan akan risiko, pemahaman aturan kepatuhan, transparansi terhadap risiko yang penting bagi perusahaan dan pendistribusian penanganan risiko di dalam perusahaan.

5. Performance measurement (pengukuran kinerja) adalah pemantauan penerapan strategi yang meliputi: proses kinerja, penggunaan sumber daya, penyelesaian proyek dan pemberian fasilitas untuk mencapai tujuan perusahaan. 


\section{3) Hubungan Tata Kelola Teknologi Informasi Dengan Bisnis Perusahaan}

IT Governance Institute (2007) [3] memberikan gambaran bahwa pengelolaan TI adalah bagian yang perlu diperhatikan dalam tata kelola perusahaan. Jadi semakin bisnis berkembang maka kebutuhan terhadap teknologi informasi semakin meningkat. Teknologi informasi nantinya membantu membangun strategi bisnis perusahaan. Dalam hal ini, pengelolaan TI membantu perusahaan dalam peningkatan keuntungan secara maksimal dari informasi yang menjadi kebutuhan perusahaan.

COBIT, menurut [10], dirancang untuk membantu pengelolaan teknologi informasi, terkait dengan pemahaman, manajemen risiko dan manfaat teknologi informasi. COBIT merupakan model kerja yang mendukung para manajer dalam pengurangan gap antara pengendalian, kebutuhan teknis, dan risiko bisnis. Langkah ini dilakukan dengan cara mengkomunikasikan tingkat pengendalian tersebut kepada para dewan direksi. COBIT dapat menjadi model proses menyeluruh yang melingkupi semua proses yang biasanya ada dalam fungsi teknologi informasi. COBIT juga menyediakan model sebagai referensi umum yang dapat dipahami oleh manajer dalam rangka operasionalisasi teknologi informasi dalam bisnis perusahaan. COBIT membantu memetakan fokus area pengelolaan teknologi informasi bagi perusahaan.

Penerapan COBIT mendorong terciptanya kebijakan TI yang jelas dan prosedur bisnis yang sesuai dengan pengelolaan TI pada seluruh aktivitas perusahaan. Ratih et al. [9] menjelaskan COBIT juga sangat berguna bagi pengguna teknologi informasi karena membantu mereka mendapatkan kepercayaan signifikansi sistem aplikasi. Selanjutnya, para manajer akan mendapatkan manfaat dalam keputusan investasi teknologi informasi bersama dengan infrastrukturnya, merencanakan rencana teknologi informasi strategis, memilih arsitektur informasi dan pengadaan sistem. Penerapan COBIT akan mendukung manajemen perusahaan dalam optimalisasi investasi teknologi informasi melalui penilaian yang memberikan peringatan terhadap kesalahan atau risiko yang mungkin terjadi dari kesalahan penerapan teknologi.

\section{4) Kerangka Kerja COBIT (COBIT Framework)}

Kerangka COBIT 4.1 dari IT Governance Institute (2007) adalah kumpulan dari praktik terbaik pengelolaan TI yang dapat diterapkan pada semua bentuk perusahaan untuk memperbaiki pengelolaan teknologi informasi [12]. Dalam proses ini COBIT memiliki tiga komponen utama yang membentuk dimensi dalam kubus COBIT yang dapat dilihat pada Gambar 1.

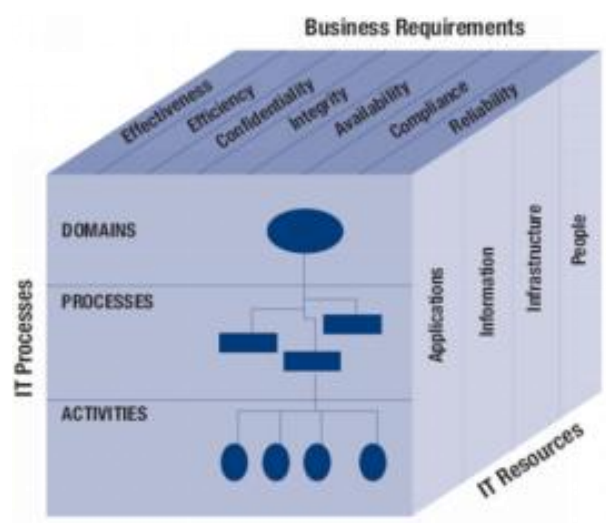

Gambar 1. The COBIT Cube menjelaskan kerangka COBIT 4.1.

Framework COBIT terbentuk dari 3 tingkat tujuan pengendalian, yang terdiri dari tugas, proses, dan domain. Tugas merupakan aktivitas rutin yang berkelanjutan dan diterapkan secara terpisah. Tugas-tugas ini akan dimasukan ke dalam kelompok proses teknologi informasi yang memiliki permasalahan. Proses tata kelola teknologi informasi yang sama dan dikelompokan ke dalam satu domain.

Framework COBIT memiliki empat domain untuk menilai kematangan dari penerapan teknologi informasi di perusahaan. Domain tersebut dibagi menjadi empat domain utama COBIT, yaitu:
a. Plan dan Organize (PO)
b. Acquisition dan Implementation (AI)
c. Delivery dan Support (DS)
d. Monitoring dan Evaluation (ME)

Hubungan dari ke-empat domain di atas bisa dilihat pada Gambar 2. 


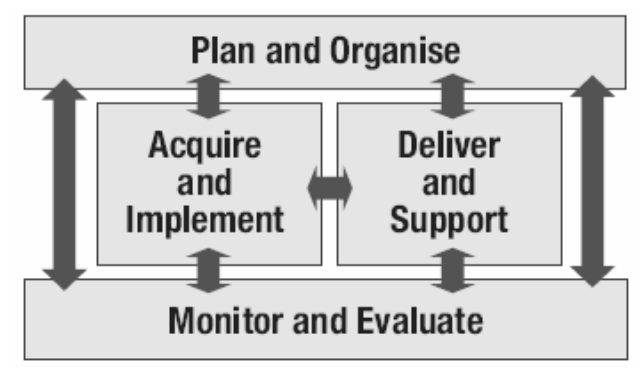

Gambar 2. Hubungan Domain COBIT 4.1

Domain Plan dan Organise (PO) memberikan rencana atau panduan untuk mendesain solusi yang nantinya bisa digunakan sebagai implementasi (AI) dan layanan pengiriman dan dukungan (DS). Domain Acquire dan Implement (AI) menyediakan solusi untuk mengarahkan atau menetapkan layanan pada pengguna. Domain Deliver dan Support (DS) menerima solusi kemudian melaksanakan solusi tersebut. Terakhir Monitor dan Evaluate (ME) digunakan untuk memonitor proses untuk menilai pengelolaan teknologi telah sesuai arah yang diberikan. Kemudian dalam [12] dan IT Governance Institute [3] dalam domain COBIT terdapat 34 proses yang sesuai dengan perkembangan ruang lingkup; tujuan dan bagian-bagian yang bertanggung jawab terhadap perencanaan tata kelola teknologi informasi. Dalam 34 proses ini telah meliputi aktivitas pembangunan, pelaksanaan, pemantauan penerapan teknologi informasi; pemberian pandangan mengenai teknologi informasi; dan menguji model kematangan tiap masing masing proses.

\section{B. Masalah Pengelolaan TI pada PT. SAE}

Berdasarkan observasi dan wawancara yang dilakukan pada PT. SAE, pokok-pokok permasalahan penting yang ada telah diidentifikasi pada bidang teknologi informasi dan perlu menjadi perhatian untuk perkembangan perusahaan selanjutnya. Pokokpokok permasalahannya yaitu sebagai berikut:

1. Strategi teknologi informasi dan strategi bisnis tidak sejalan. Kondisi ini terjadi karena belum diidentifikasi faktor strategi teknologi informasi perusahaan secara menyeluruh.

2. Infrastruktur TI pada PT. SAE masih hanya sebatas pendukung (support) dalam kinerja di perusahaan. Dalam masalah ini, manajemen belum memiliki rencana strategi terkait dengan peran atau dukungan teknologi informasi untuk memaksimalkan fungsi dari kegiatan operasional utama perusahaan yaitu, produksi.

3. Kurangnya keterlibatan manajemen puncak PT. SAE dalam penentuan arah, kebijakan, strategi perusahaan dan pemanfaatan teknologi informasi untuk mendukung kegiatan utama perusahaan yaitu produksi kabel.

Dari masalah yang dapat diidentifikasi, dapat diidentifikasi bahwa PT. SAE belum memiliki framework yang jelas terkait dengan pengelolaan teknologi informasi. Oleh karena itu, COBIT 4.1. ditawarkan sebagai bentuk framework yang dapat diadopsi oleh PT. SAE untuk memaksimalkan peran teknologi informasi dalam bisnisnya

\section{Metode Penelitian}

Penelitian ini adalah penelitian studi kasus. Menurut Nasution [13], studi kasus merupakan penelitian yang mendalami kondisi lingkungan sosial dalam suatu konteks yang dapat terdiri dari individu, kelompok, lingkungan manusia atau lembaga sosial. Tujuan penggunaan studi kasus adalah untuk menjelaskan bagaimana gap tingkat kematangan TI dapat terjadi.

\section{Tahapan Penelitian}

Data penelitian ini diperoleh dengan menggunakan dua tahap. Pertama adalah mendapatkan informasi tentang management awareness. Tahap ini dilakukan untuk mendapatkan gambaran mengenai kebutuhan atau prioritas penerapan teknologi informasi di PT. SAE dengan menyebarkan kuesioner. Responden kuesioner tahap pertama adalah pihak yang memahami rencana pengembangan teknologi pada perusahaan. Tahap kedua adalah analisis tingkat kematangan pengelolaan teknologi informasi. Hasil proses dua dilakukan dengan mendistribusikan kuesioner terhadap manajemen tingkat tengah dan bawah. Kedua, hasil tahap pertama dan kedua akan dibandingkan, yaitu perbandingan antara praktik penerapan teknologi informasi dengan rencana pengelolaan teknologi, sesuai dengan COBIT 4.1. Tahap ini dilakukan untuk menilai tingkat kesenjangan (tingkat kematangan) antaran harapan perusahaan dan praktik penerapan teknologi informasi.

\section{E. Pengukuran Tingkat Kematangan TI}

Tingkat kematangan menurut IT Governance Institute (2007) [14] merupakan sebuah metode untuk menilai sebaik apa implementasi pengelolaan TI di suatu organisasi. Adapun tingkat kematangan yang terdapat dalam model COBIT yaitu: 
1. Nilai 0: Non-Existent $(0,00-0,49)$. Kondisi ini menunjukkan kelemahan atau kekurangan pada semua proses yang telah diidentifikasi. Pada tahap ini belum terdapat standarisasi prosedur.

2. Nilai 1: Initial/Ad hoc $(0,50-1,49)$. Kondisi ini menunjukkan bahwa prosedur telah dibuat dan diterapkan pada beberapa aktivitas organisasi yang dapat diidentifikasi. Rangkaian prosedur yang ada telah dipatuhi oleh pihak-pihak yang terlibat. Namun, pada tahap ini belum terdapat pelatihan secara formal, dan pelaksanaan tanggung jawab diserahkan kepada masing-masing pihak yang terkait proses tersebut. Pada tahap ini perusahaan memberikan tingkat kepercayaan yang tinggi terhadap pihak tertentu sehingga kemungkinan untuk terjadi kesalahan pada masing-masing pihak masih sangat besar.

3. Nilai 2: Repeatable but intuitive $(1,50-2,49)$. Kondisi ini menunjukkan bahwa proses telah dibuat pada tahapan yang lebih detail dimana prosedur yang ada telah dipatuhi oleh berbagai pihak pada tugas yang sama. Pada tahap ini, tidak terdapat pelatihan secara formal terhadap prosedur standar, dan pelaksanaan tanggung jawab diserahkan kepada masingmasing individu sesuai prosedur. Pada tahap ini terdapat tingkat kepercayaan yang tinggi terhadap kemampuan individu sehingga kemungkinan terjadi kesalahan masih sangat tinggi.

4. Nilai 3: Defined $(2,50-3,49)$. Kondisi ini menunjukkan prosedur telah standar yang telah ditentukan kemudian disampaikan melalui pelatihan. Prosedur yang ada telah diwajibkan untuk diikuti. Namun prosedur tersebut masih tidak lengkap walaupun sudah terdapat praktik formal yang berlaku.

5. Nilai 4: Manage dan Measurable (3,50 - 4,49). Kondisi ini menunjukkan bahwa manajemen telah melakukan pengendalian dan penilaian kepatuhan dari prosedur yang ada, serta mengambil tindakan tertentu jika prosedur tersebut tidak tepat. Pada tahap ini proses telah dikembangkan dalam rangka meningkatkan hasil dan hadirnya praktik terbaik. Pada tahap ini, prosedur otomatis telah dilakukan dengan ketentuan khusus pada tahap ini.

6. Nilai 5: Optimised (4,50 - 5,00). Kondisi ini menunjukkan proses ini berada pada tingkat praktik yang terbaik, dengan hasil dari perbaikan yang berkelanjutan. Dalam tahap ini, teknologi informasi telah digunakan sebagai cara integrasi dalam otomatisasi prosedur kerja, peningkatan kualitas dan efektifitas, dan mendorong perusahaan untuk mampu cepat menyesuaikan diri dengan kebutuhan lingkungan bisnis.

\section{F. Pengolahan dan Analisis Data}

Setelah pengumpulan data dilakukan, langkah selanjutnya dalam penelitian ini adalah analisis data. Analisis data dalam COBIT terdiri dari analisis tingkat kematangan pada kondisi saat ini, analisis tingkat kematangan yang diinginkan perusahaan, dan analisis gap (kesenjangan) antara kondisi saat ini dengan kondisi yang diinginkan perusahaan [15]. Hasil dari analisis kesenjangan dilakukan untuk menilai tingkat kematangan (maturity level) pada penerapan pengelolaan teknologi informasi di perusahaan tersebut. Pengelolaan dan analisis dilakukan dengan menggunakan aplikasi Microsoft excel.

1. Analisis Tingkat Kematangan Perusahaan Saat Ini.

Analisis ini merupakan analisis untuk mengevaluasi tingkat kematangan pengelolaan TI saat ini (disebut: $a s$ - is). Penilaian dilakukan pada proses dari domain yang dipilih berdasarkan prioritas perusahaan saat ini. Masing-masing proses dari domain yang dipilih tersebut kemudian dinilai tingkat kematangan tata kelola TI untuk menilai tingkat realisasi penerapan TI perusahaan. Indeks tingkat kematangan atribut diperoleh dari jumlah nilai jawaban dibagi dengan jumlah pertanyaan kuesioner dikali dengan jumlah responden seperti pada rumus persamaan (1):

$$
\text { IndeksKematanganAtribut }=\frac{\text { (jumlahnilaijawaban) }}{\text { (jumlahpertanyaankuesionerxjumlahresponden) }}
$$

2. Analisis Tingkat Kematangan Yang Diinginkan

Selain analisis realisasi tingkat kematangan, COBIT juga melakukan analisis tingkat kematangan pada tata kelola TI yang diinginkan perusahaan (disebut: to - be). Analisis tingkat kematangan yang diinginkan, dilakukan dalam rangka memberikan arahan pada pengembangan pengelolaan TI pada suatu perusahaan. Penilaian tingkat kematangan pengelolaan TI yang diinginkan perusahaan, diperoleh dari pertimbangan beberapa faktor termasuk ekspektasi yang tinggi oleh manajemen.

3. Analisis Gap (Kesenjangan)

Setelah analisis tingkat kematangan pada saat ini dan tingkat kematangan yang diharapkan dilakukan, langkah selanjutnya akan dilakukan analisis kesenjangan (gap analysis). Analisis kesenjangan bertujuan untuk memberikan kemudahan perbaikan pengelolaan TI oleh manajemen. Penilaian tingkat kesenjangan ini dilakukan dengan membandingkan tingkat kematangan tata kelola TI yang diharapkan dengan tingkat realisasi kematangan tata kelola TI. Dari analisis tersebut dapat dinilai proses yang belum sesuai dengan yang diharapkan sehingga dapat dianalisis untuk mendapat perbaikan.

Perbaikan tersebut nantinya berupa rekomendasi yang diharapkan dapat mampu memberikan referensi kepada manajemen dalam implementasi teknologi informasi di perusahaan. Rekomendasi perbaikan akan dibuat dari subdomain framework COBIT 4.1 sebagai acuan. Walaupun demikian, rekomendasi perbaikan akan disesuaikan dengan kemampuan perusahaan. Penilaian tingkat 
kesenjangan didapat dari persamaan (2), yaitu: tingkat kematangan yang diinginkan perusahaan dikurangi dengan tingkat realisasi kematangan saat ini:

Tingkatkesenjangan $=X-Y$

Keterangan:

$\mathrm{X}=$ Tingkat kematangan yang diinginkan $(t o-b e)$

$\mathrm{Y}=$ Tingkat realisasi kematangan $(a s-i s)$

\section{HASIL DAN PEMBAHASAN}

\section{A. Profil Responden}

Responden penelitian ini adalah kepala masing-masing divisi pada PT. SAE yang terdiri dari 8 orang terdiri dari Supervisor Accounting, Supervisor HRD, Supervisor Purchasing, Supervisor IT, Supervisor M\&E, Supervisor QC, Supervisor Logistic dan Supervisor Production.

\section{B. Management Awareness}

Pada tahap ini pemilihan proses TI yang teridentifikasi berdasarkan kuesioner awal (kuesioner management awareness) yang berisi seluruh indikator-indikator (domains) menurut COBIT framework 4.1. Tahap ini dilakukan untuk dapat mengukur pengelolaan TI dengan konsep COBIT 4.1 namun disesuaikan dengan konteks, permasalahan, dan kebutuhan teknologi perusahaan. Identifikasi proses TI tersebut dilihat berdasarkan pilihan jawaban sangat penting dan sangat prioritas dari tiap-tiap indikator (domains) oleh responden tentang kebutuhan perusahaan saat ini.

Responden pengisian kuesioner management awareness ini adalah Supervisor IT pada PT. SAE. Supervisor IT dipilih karena dari hasil observasi wawancara menunjukkan bahwa kepala departemen TI atau Supervisor IT telah mendapatkan mandat atau otoritas untuk mengelola teknologi oleh direktur perusahaan. Adapun hasil kuesioner management awareness terhadap proses TI yang terpilih atau teridentifikasi adalah domain tertentu seperti pada Tabel 1.

TABEL 1

HASIL KUESIONER MANAGEMENT AWARENESS TERIDENTIFIKASI PADA PT. SAE

\begin{tabular}{ll}
\hline \multicolumn{1}{c}{ Domain TI } & \multicolumn{1}{c}{ Proses TI } \\
\hline Plan dan Organize (PO) & PO2: Define the Information Architecture (4 pertanyaan) \\
& PO3: Determine Technological Direction (5 pertanyaan) \\
& PO6: Communicate Management Aims and Directions (5 pertanyaan) \\
& PO7: Manage IT human resource (8 pertanyaan) \\
& PO10: Manage Projects (14 pertanyaan) \\
\hline Acquire dan Implementation (AI) & AI2: Acquire and maintain application software (10 pertanyaan) \\
& AI3: Acquire and maintain technology infrastructure (4 pertanyaan) \\
& AI4: Produce IT resource (4 pertanyaan) \\
& AI5: Produce IT resource (4 pertanyaan) \\
& AI7: Install and Accredit Solution and Changes (9 pertanyaan) \\
\hline Deliver dan Support (DSS) & DS2: Manage Third-party service (4 pertanyaan) \\
& DS3: Manage performance and capacity (5 pertanyaan) \\
& DS5: Ensure Systems Security (11 pertanyaan) \\
& DS8: Manage service desk and incident (5 pertanyaan) \\
& DS10: Manage problems (4 pertanyaan) \\
& DS11: Manage data (6 pertanyaan) \\
\hline Monitor dan Evaluation (ME) & ME1: Monitor and Evaluate Internal Control (4 pertanyaan) \\
& ME4: Provide IT Governance (4 pertanyaan) \\
\hline
\end{tabular}

\section{Penilaian kuesioner}

Menurut IT Governance Institute (2007) [3], skala interval pembuatan indeks memiliki pemetaan ke tingkat maturity model untuk membantu dalam memahami hasil dari perhitungan kuesioner. Skala interval diberikan untuk masing-masing skor dari hasil kuesioner yang diperoleh. Skala Interval skor dapat dilihat pada Tabel 2. 
TABEL 2

Skala Pengukuran Kuesioner

\begin{tabular}{cl}
\hline Skor yang diberikan & \multicolumn{1}{c}{ Deskripsi Skor } \\
\hline 0 & Tidak adanya prosedur pengelolaan TI. \\
\hline 1 & $\begin{array}{l}\text { Dilakukan pengelolaan TI tetapi tidak } \\
\text { ada prosedur. }\end{array}$ \\
\hline 2 & $\begin{array}{l}\text { Dilakukan dilakukan pengelolaan TI } \\
\text { tetapi prosedur belum baku. }\end{array}$ \\
\hline 3 & $\begin{array}{l}\text { Dilakukan dilakukan pengelolaan TI } \\
\text { dengan prosedur tidak lengkap namun } \\
\text { sudah praktik formal yang berlaku. }\end{array}$ \\
\hline 4 & $\begin{array}{l}\text { Dilakukan pengelolaan TI yang sudah } \\
\text { baku dan ada prosedur lengkap, serta } \\
\text { ada pengawasan. }\end{array}$ \\
\hline 5 & $\begin{array}{l}\text { Pengelolaan TI sudah sempurna, } \\
\text { prosedur bekerja dengan baik dan } \\
\text { perusahaan dapat dengan cepat } \\
\text { beradaptasi dalam perubahan }\end{array}$ \\
\hline
\end{tabular}

Dalam melakukan pengukuran tingkat kematangan PT. SAE, digunakan kuesioner sebagai metode pengumpulan data yang akan memiliki nilai indeks pada masing-masing kriteria dari pengukuran yang dilakukan yaitu dengan menggunakan persamaan (3) berikut:

$$
\text { Indeks }=\frac{(\text { jumlahnilaijawaban })}{(\text { jumlahpertanyaankuesionerxjumlahresponden })}
$$

\section{Pengolahan Data Kuesioner}

Untuk mengetahui gap pada masing-masing domain, perlu dilakukan perbandingan tingkat kematangan antara nilai rata-rata tiap proses dengan target yang ditetapkan. Target dilihat berdasarkan visi, misi perusahaan PT. SAE, wawancara dengan responden dan hasil pemilihan kuesioner pertama mengenai management awareness dilihat berdasarkan jawaban sangat penting. Hasil dari jawaban kuesioner dari responden ditampilkan pada Tabel 3.

TABEL 3

HASIL KUESIONER RESPONDEN

\begin{tabular}{|c|c|c|c|c|c|}
\hline Proses & $\begin{array}{l}\text { Total Nilai Kuesioner } \\
\text { (A) }\end{array}$ & $\begin{array}{l}\text { Total Pertanyaan } \\
\text { (B) }\end{array}$ & $\begin{array}{c}\text { Jumlah Responden } \\
\text { (C) }\end{array}$ & $\begin{array}{l}\text { Total Pertanyaan } x \text { Jumlah Responden } \\
\text { (D) }\end{array}$ & $\begin{array}{l}\text { Indeks } \\
(\mathrm{A}) /(\mathrm{D})\end{array}$ \\
\hline $\mathrm{PO} 2$ & 111 & 4 & 8 & 32 & 3.47 \\
\hline PO3 & 132 & 5 & 8 & 40 & 3.30 \\
\hline PO6 & 124 & 5 & 8 & 40 & 3.10 \\
\hline PO7 & 280 & 11 & 8 & 88 & 3.18 \\
\hline $\mathrm{AI} 3$ & 95 & 4 & 8 & 32 & 2.97 \\
\hline $\mathrm{AI} 4$ & 102 & 4 & 8 & 32 & 3.19 \\
\hline AI5 & 89 & 4 & 8 & 32 & 2.78 \\
\hline $\mathrm{AI7}$ & 218 & 9 & 8 & 72 & 3.03 \\
\hline DS10 & 97 & 4 & 8 & 32 & 3.03 \\
\hline DS11 & 139 & 6 & 8 & 48 & 2.90 \\
\hline ME1 & 89 & 4 & 8 & 32 & 2.78 \\
\hline ME4 & 117 & 5 & 8 & 40 & 2.93 \\
\hline \multicolumn{5}{|c|}{ TOTAL INDEKS } & 54.76 \\
\hline \multicolumn{5}{|c|}{ RATA-RATA INDEKS } & 3.04 \\
\hline
\end{tabular}


Hasil kuesioner tersebut dapat diketahui bahwa nilai rata-rata pencapaian pengelolaan teknologi adalah 3,04. Dari hasil ini analisis tingkat kematangan pengelolaan TI dapat dilakukan. Tabel 4 menunjukkan perbandingan tingkat kematangan pada setiap domain.

TABEL 4

Perbandingan Tingkat Kematangan Pada Setiap Domain

\begin{tabular}{cccc}
\hline \multirow{2}{*}{ Proses } & \multicolumn{3}{c}{ Tingkat Kematangan } \\
\cline { 2 - 4 } & Sekarang & Target & Gap \\
\hline PO2 & 3,47 & 5 & 1,53 \\
\hline PO3 & 3,30 & 5 & 1,70 \\
\hline PO6 & 3,10 & 5 & 1,90 \\
\hline PO7 & 3,18 & 5 & 1,82 \\
\hline PO10 & 3,24 & 5 & 1,76 \\
\hline AI2 & 3,05 & 5 & 1,95 \\
\hline AI3 & 2,97 & 5 & 2,03 \\
\hline AI4 & 3,19 & 5 & 1,81 \\
\hline AI5 & 2,78 & 5 & 2,22 \\
\hline AI7 & 3,03 & 5 & 1,97 \\
\hline DS2 & 2,84 & 5 & 2,16 \\
\hline DS3 & 2,80 & 5 & 2,20 \\
\hline DS5 & 3,16 & 5 & 1,84 \\
\hline DS8 & 3,03 & 5 & 1,97 \\
\hline DS10 & 3,03 & 5 & 1,97 \\
\hline DS11 & 2,90 & 5 & 2,10 \\
\hline ME1 & 2,78 & 5 & 2,22 \\
\hline ME4 & 2,93 & 5 & 2,07 \\
\hline Total & 54,8 & 90 & 35,2 \\
\hline Rata-Rata Indeks & 3,04 & 5 & 1,96 \\
\hline & & &
\end{tabular}

Tabel 4 menunjukkan tingkat kematangan pengelolaan teknologi pada PT. SAE adalah rata-rata 3,04. Hasil tersebut menunjukkan bahwa secara umum pengelolaan TI sudah dilakukan dengan beberapa praktik formal prosedur pengelolaan TI walaupun belum lengkap. Dari hasil perbandingan pada tabel 4 dapat dipahami bahwa ada selisih antara target yang diharapkan dengan realisasi pencapaian pengelolaan TI, yaitu sebesar 1,96. Dilihat dari rata-rata nilai yang diperoleh dapat diartikan bahwa pengelolaan teknologi informasi yang diterapkan telah mencapai tahap defined process. Pada tingkat ini, dapat dikatakan bahwa proses standar dalam pengembangan telah didokumentasikan sebagian. Proses ini dibentuk dengan dasar proses pengembangan yang telah terintegrasi. Secara lengkap selisih tingkat pencapaian ini dijelaskan lebih rinci pada Gambar 3.

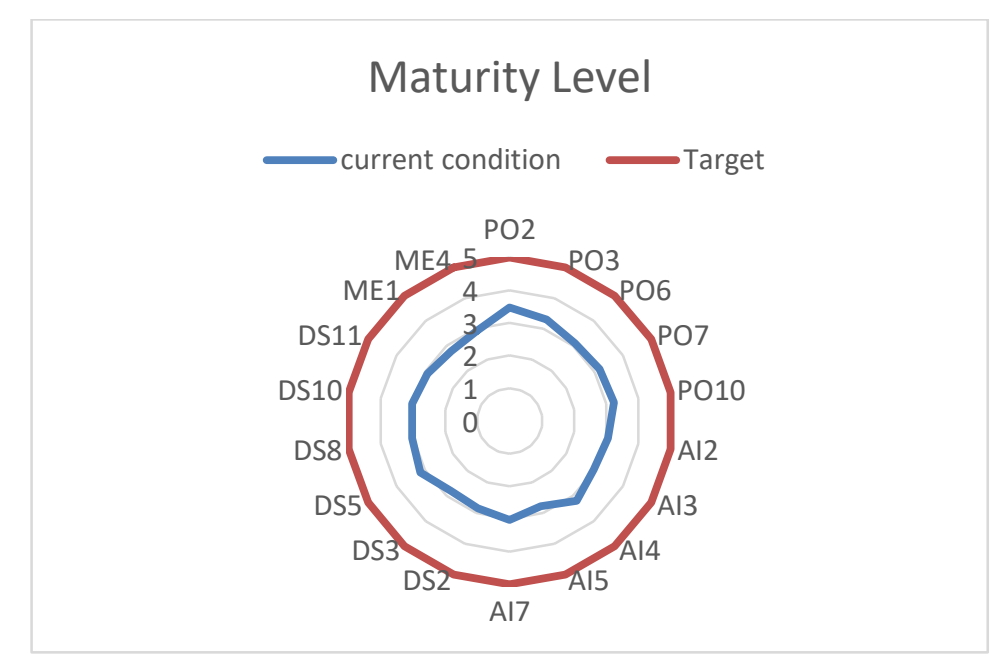

Gambar 3. Situasi tingkat kematangan TI pada PT. SAE. 
Pada tahap realisasi pengelolaan TI, proses-proses yang ada digunakan untuk membantu manajemen untuk mencapai efektivitas kerja dengan lebih baik. Prosedur dan tanggung jawab sudah ditentukan dengan jelas sebagian. Karena prosedur dalam software belum semuanya ditentukan dengan detail, oleh karena itu manajemen tidak mempunyai informasi yang menyeluruh terkait dengan perkembangan proyek yang meliputi biaya, jadwal, kebutuhan pengawasan proyek dan kualitas produk.

\section{E. Analisis dan Pembahasan}

Dari hasil perhitungan pada tabel III, nilai rata-rata pengelolaan teknologi informasi PT. SAE adalah sebesar 3,04 sedangkan tingkat kematangan yang menjadi target untuk dicapai oleh PT. SAE adalah level 5 (gambar 4). Dari perbandingan tersebut dapat diperoleh selisih sebesar 1.96 hal ini menunjukkan bahwa belum tercapainya target tingkat kematangan seperti yang diharapkan oleh PT. SAE. Pada posisi ini PT. SAE telah mampu mendefinisikan proses pengelolaan TI walaupun belum semua.

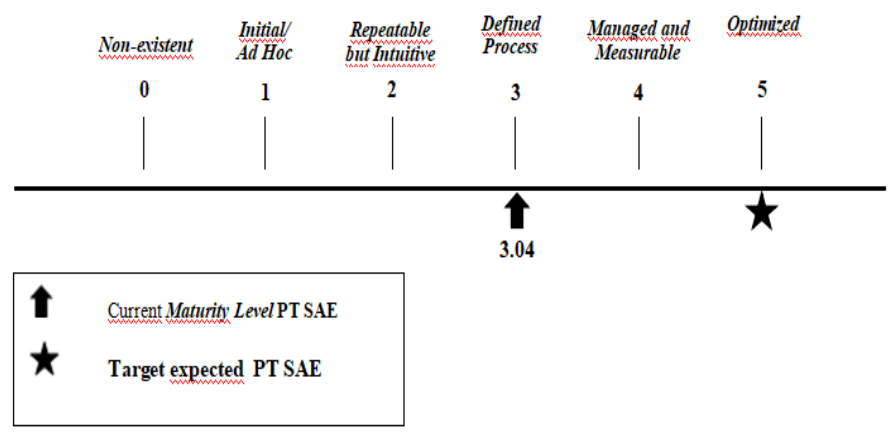

Gambar 4. Tingkat Kematangan Pengelolaan TI Perusahaan

Dari hasil analisis tingkat kematangan berdasarkan COBIT 4.1. PT. SAE, dalam pengelolaan TI, masih memiliki beberapa kelemahan. Kelemahan tersebut ada pada domain Acquire and Implementation (AI3, AI5), Deliver and Support (DS2, DS3, DS11), dan Monitor and Evaluation (ME1, ME4). Kelemahan tersebut dapat dilihat pada nilai masing-masing indikator tersebut berada pada di bawah rata-rata pencapaian perusahaan yaitu di bawah 3,04.

\section{F. Kelemahan Domain Acquire dan Implementation (AI)}

Hasil perhitungan yang diperoleh menunjukkan bahwa indikator AI3 memiliki nilai sebesar 2,97. AI3 merupakan indikator terkait dengan bagaimana infrastruktur teknologi informasi diperoleh dan dipelihara. Nilai AI3 yang mencapai 2,97 masih terdapat gap yang cukup tinggi yaitu sebesar 2.03. Kondisi ini termasuk dalam golongan Defined Process. Artinya proses pengelolaan TI telah terdefinisi namun pada praktiknya belum semua proses maksimal dijalankan. Dari hasil wawancara, pengelolaan infrastruktur, strategi dan optimasi sumber daya PT. SAE sudah dilakukan namun pendokumentasian hasil belum diterapkan secara menyeluruh. Masalah ini disebabkan oleh sumber daya perusahaan yang kurang mendukung. Kekurangan ini meliputi kompetensi sumber daya manusia dan sarana teknologi yang meliputi platform hardware komputer dan platform internet yang lambat. Untuk masalah ini, perusahaan memerlukan perencanaan sesuai dengan strategi teknologi, pembangunan dan lingkungan pengujian [16].

Selain masalah dalam penerapan AI3, dalam domain ini perusahaan juga memiliki kekurangan dalam penerapan AI5. Indikator domain AI5 merupakan indikator yang menunjukkan pengelolaan TI dalam bentuk pengadaan sumber daya TI. Hasil perhitungan yang diperoleh, menunjukkan indikator AI5 mendapat nilai sebesar 2.78. Dalam kondisi ini, perusahaan masuk ke dalam golongan defined process, namun masih terdapat gap yang cukup jauh dari target yang diharapkan, yaitu sebesar 2.22. Berdasarkan hasil wawancara yang dilakukan, pengadaan sumber daya TI sudah tersedia tetapi terdapat beberapa prosedur yang belum sesuai dengan kebutuhan bisnis seperti belum terdapatnya prosedur pengembangan sistem dikarenakan masih banyaknya karyawan yang belum memenuhi standar pendidikan dan pelatihan TI. Masalah ini menyebabkan pemborosan biaya dan waktu sehingga perusahaan menjadi tidak efisien [17].

Dari keterangan narasumber yang diperoleh dapat disimpulkan bahwa perusahaan memiliki masalah dalam hal detail infrastruktur TI yang dibutuhkan dan kebutuhan sumber daya manusia yang sesuai untuk teknologi yang diterapkan. Dalam kondisi tersebut, upaya untuk meningkatkan tingkat kematangan adalah, pertama, melakukan pendokumentasian strategi dan perancangan prosedur yang sesuai dengan kebutuhan proses saat ini dan proyeksi kebutuhan di masa mendatang. Kedua, pengembangan infrastruktur TI secara bertahap dan berkesinambungan yang sesuai dengan kebutuhan. Identifikasi kebutuhan merupakan langkah awal untuk dapat melakukan pengadaan infrastruktur yang tepat termasuk di dalamnya adalah kebutuhan kompetensi karyawan yang sesuai dengan rencana strategis perusahaan[18]. 


\section{G. Kelemahan Domain Deliver dan Support (DS)}

Berdasarkan hasil perhitungan yang diperoleh pada domain ini, perusahaan memiliki kelemahan pada pengelolaan pada pihak ketiga (indikator DS2), pengelolaan kinerja dan kapasitas (indikator DS3), dan pengelolaan data (indikator DS11). Masing-masing nilai pada indikator adalah sebesar 2,84; 2,80; 2,90, dimana nilai tersebut berada di bawah rata-rata penilaian total yaitu 3,04. Pada nilai tersebut proses ini dapat dikategorikan ke dalam golongan defined process namun masih terdapat gap yang cukup jauh dari yang ditargetkan.

Berdasarkan hasil wawancara dan observasi, kelemahan pada domain ini disebabkan karena sifat penerapan teknologi informasi yang ada di perusahaan adalah bersifat sebagai aktivitas pendukung. Sebagai aktivitas pendukung kegiatan utama perusahaan, aktivitas pengelolaan teknologi tidak akan berdampak langsung pada peningkatan pendapatan perusahaan. Oleh karena itu, pelaksanaan aktivitas pengelolaan teknologi informasi bukan yang utama. Walaupun demikian, keberadaan aktivitas pendukung ini sangat penting untuk dapat meningkatkan efisiensi operasional perusahaan yang memiliki dampak pada peningkatan laba perusahaan [18]. Akan tetapi, alangkah lebih baik jika relasi TI dan bisnis mampu bersinergi dan TI dianggap sebagai pendukung penyedia layanan yang bernilai [19].

Contoh kasus yang terjadi adalah dalam layanan dengan pihak ketiga, PT. SAE telah melakukan peninjauan secara langsung terkait dengan prosedur pengadaan barang dari supplier namun prosedur pengadaan barang tersebut beberapa prosedur detail belum teridentifikasi dengan lengkap. Dampak kejadian ini yaitu tidak adanya persyaratan akan kebijakan atau prosedur formal untuk menyelesaikan masalah yang dapat terjadi antara kedua pihak. Masalah ini disebabkan kurangnya pemanfaatan peralatan teknologi informasi dalam mendukung dan mendokumentasikan kebijakan, prosedur serta membantu dalam hal pelaksanaan kontrak dengan pihak ketiga.

Sebagai aktivitas pendukung, perusahaan lebih fokus pada perencanaan aktivitas primer. Masalah ini menyebabkan kurangnya perencanaan kebutuhan teknologi yang berdampak pada kurangnya perencanaan kapasitas TI yang dibutuhkan [20]. Masalah ini juga berdampak pada kebutuhan data yang kurang teridentifikasi untuk pengambilan keputusan. Dari masalah ini, perusahaan perlu menyadari bahwa dukungan dari manajemen puncak merupakan kunci penting keberhasilan pengelolaan teknologi. Manajer puncak bersama dengan manajer tengah dapat menyusun konsep pengelolaan teknologi informasi untuk dapat mendukung aktivitas utama perusahaan [3]. Kepuasan pengguna sistem informasi juga perlu dievaluasi untuk mengetahui dan mendapatkan umpan balik dari pengguna sistem untuk mendefinisikan kebutuhan sistem [21]. Dengan demikian sistem dapat dikembangkan sesuai dengan kebutuhan perusahaan namun juga sesuai dengan kebutuhan pengguna.

\section{H. Kelemahan Domain Monitor dan Evaluation (ME)}

Pada domain ini, perusahaan memiliki kelemahan pada evaluasi kinerja TI (indikator ME1) dan penerapan tata kelola TI (indikator ME4). Kedua indikator tersebut mendapatkan hasil di bawah nilai rata-rata (3,04), yaitu 2,78 dan 2,93. Dengan perolehan nilai tersebut maka pada domain ini dapat dikategorikan ke dalam kategori defined process yang artinya adalah beberapa proses pengelolaan TI telah terdefinisi dan dilakukan namun belum diterapkan secara terstruktur dan menyeluruh.

Berdasarkan hasil observasi, kelemahan pada domain ini disebabkan oleh perhatian manajer puncak yang kurang terhadap pengelolaan TI. Masalah ini disebabkan karena peran TI yang hanya sebagai aktivitas pendukung sehingga pengelolaan TI belum mendapat perhatian serius baik dari segi anggaran dan kebijakan [1]. Dalam hal ini, manajemen perlu untuk merumuskan ulang struktur pengelolaan TI dalam strategi bisnis mereka. dengan struktur bisnis yang jelas, perusahaan akan dapat mengukur pencapaian manfaat teknologi informasi untuk meningkatkan nilai bisnis mereka.

\section{Keselarasan Bisnis}

Hosseinbeig et al. [8] menjelaskan bahwa terdapat kaitan yang erat antara tingkat kematangan pengelolaan TI dengan keselarasan TI. Semakin tinggi tingkat kematangan pengelolaan TI organisasi maka penerapan TI semakin selaras dengan bisnis. Hal ini berarti bahwa organisasi telah mampu menempatkan TI dalam struktur bisnis organisasi, sehingga organisasi dapat memaksimalkan nilai bisnis atau nilai perusahaan. Hasil penelitian ini menunjukkan nilai tingkat kematangan pengelolaan TI adalah sebesar 3,04. Nilai ini secara tidak langsung menunjukkan bahwa tingkat keselarasan TI dan bisnis pada level 3, yaitu: perusahaan telah memahami peran dukungan TI terhadap bisnis. Perusahaan telah mampu meletakkan TI dalam struktur bisnis, namun belum semua proses dapat didefinisikan. Pada tahap ini perusahaan telah dapat menilai peran penting kegunaan TI untuk mendukung kelancaran bisnis utama perusahaan [18], [22].

Kurang maksimalnya keselarasan TI dengan bisnis disebabkan antara lain oleh pengelolaan TI perusahaan yang memiliki kelemahan pada domain Acquire dan Implementation (AI3, AI5), Deliver dan Support (DS2, DS3, DS11), Monitor dan Evaluation (ME1, ME4). Hasil observasi menunjukkan bahwa masalah ini disebabkan antara lain karena kurangnya dukungan manajemen puncak yang berdampak pada perencanaan TI dalam struktur bisnis kurang maksimal. Dalam hal ini domain Plan dan organize (PO) mendapatkan 3,25. Dalam hal ini domain PO belum maksimal. Kondisi tersebut, secara mendasar, disebabkan oleh kurangnya dukungan manajemen puncak, sehingga peran strategi TI kurang diperhatikan.

Struktur organisasi menunjukkan bahwa departemen TI berada di bawah direktur utama. Posisi ini menunjukkan bahwa kepala departemen TI memiliki peran penting dalam membantu manajemen puncak untuk mendefinisikan peran dan fungsi TI. Hasil 
observasi menunjukkan bahwa kepala departemen TI tidak atau kurang memiliki latar belakang bisnis. pada masalah ini, komunikasi merupakan langkah awal dalam menciptakan atau meningkatkan pemahaman bisnis dan TI, sehingga manajemen puncak dan kepala departemen TI memiliki pemahaman yang sama terhadap bisnis dan teknologi [22]

Luftman menjelaskan bahwa komunikasi adalah tahap awal untuk membangun pemahaman ide bisnis [23]. Dalam struktur PT. SAE yang flat, komunikasi antara kepala departemen TI dan manajemen puncak, secara langsung atau tidak langsung, akan menimbulkan transfer pengetahuan pada dua pihak tersebut sehingga teknologi dapat dipahami dalam konteks bisnis yang ada. Komunikasi juga dapat dilakukan dengan analisis value TI. Hasil penelitian ini merupakan langkah awal untuk mengevaluasi nilai TI selama ini. Hasil penelitian ini mendukung pemahaman penerapan TI selama ini. Dengan demikian dengan hasil ini penelitian ini perusahaan dapat memulai meningkatkan tata kelola TI untuk meningkatkan nilai bisnis. Komunikasi juga dapat dilakukan dengan pihak luar, yaitu dengan membangun partnership [24]. perusahaan dapat bermitra dengan perusahaan penyedia jasa teknologi informasi yang memiliki pemahaman bisnis. Dengan pendekatan mitra, perusahaan juga dapat meningkatkan fleksibilitas infrastruktur TI.

Sebagai langkah akhir dalam meningkatkan atau membangun keselarasan bisnis dan TI perusahaan perlu membangun skill karyawan [22], [25], khususnya adalah kepala departemen TI untuk meningkatkan pemahaman bisnis. Pelatihan bagi karyawan perlu direncanakan untuk meningkatkan kemampuan teknis karyawan dalam penggunaan TI dan meningkatkan pemahaman bisnis karyawan. Dalam hal ini, perusahaan dapat melakukan beberapa hal:

1. Membangun atau meningkatkan komunikasi antar departemen, khususnya departemen TI dengan manajemen puncak [20].

2. Membangun value dan mengukur value bisnis organisasi. Manajemen perlu untuk melakukan penilaian pengelolaan TI secara berkala. Beberapa survei yang dapat dilakukan berkala adalah survei kepuasan terhadap kualitas sistem informasi, kepuasan terhadap kualitas informasi dan kepuasan terhadap kualitas layanan pengguna [21], [26].

3. Meningkatkan tata kelola TI. Salah satunya dengan hasil penelitian COBIT ini. Evaluasi peran TI perlu dilakukan secara berkala dengan bersama dengan para stakeholder [18], [27].

4. Membangun mitra untuk meningkatkan nilai bisnis dan teknologi. Perusahaan bisa bekerja sama dengan penyedia jasa teknologi informasi yang memiliki, tidak hanya teknologi tetapi juga memiliki konsep bisnis proses yang jelas. Supaya perusahaan dapat belajar dari perusahaan tersebut [16].

5. Menilai ruang lingkup TI dalam bisnis perusahaan dan infrastruktur yang dibangun. Manajemen puncak perlu mengembangkan pengelolaan TI pada ruang lingkup yang telah ditetapkan. Manajemen puncak perlu membangun arsitektur TI yang sesuai dengan bisnis. Hal ini akan memperjelas kebutuhan teknologi yang sesuai untuk bisnis perusahaan [28].

6. Melakukan pelatihan bisnis khususnya kepada kepala departemen TI untuk meningkatkan pemahaman bisnis. Dengan demikian fungsi direktur sistem informasi dapat dicapai tanpa merekrut orang baru atau menambah departemen baru[28].

\section{SIMPULAN}

Penelitian ini dilakukan untuk mengevaluasi praktik pengelolaan TI perusahaan dengan menggunakan framework kematangan dari COBIT 4.1, dan mengevaluasi kesesuaian teknologi informasi dengan strategi bisnis perusahaan. Berdasarkan hasil perhitungan hasil kuesioner, nilai rata-rata tingkat kematangan adalah sebesar 3,04. Berdasarkan nilai tersebut pengelolaan TI pada PT. SAE termasuk dalam golongan defined process. Kondisi tersebut menunjukkan bahwa serangkaian aktivitas yang terkait dengan proses perencanaan dan organisasi di PT. SAE telah terdefinisi. Pada tahap ini, perusahaan telah cukup baik dalam mengelola TI. Perusahaan telah mendefinisikan prosedur pengelolaan TI, tetapi belum semua aktivitas terdefinisi secara terstruktur.

Untuk mengatasi masalah perusahaan perlu untuk memiliki fungsi direktur sistem informasi (Chief Information System). Fungsi departemen teknologi saat ini lebih kepada masalah teknis teknologi. Luftman menyarankan beberapa faktor yang perlu diperhatikan untuk membangun keselarasan bisnis dengan TI [23]. Keterbatasan penelitian ini adalah kurangnya akses terhadap pimpinan puncak dari PT. SAE. Keterbatasan ini menyebabkan kurangnya informasi atau konfirmasi terhadap kebijakan perencanaan TI dan strategi bisnis perusahaan. Oleh karena itu penelitian COBIT selanjutnya dapat lebih fokus untuk mengkaji keselarasan TI dengan bisnis perusahaan. Model keselarasan dari Luftman [24] dapat digunakan sebagai langkah lanjut pengembangan sistem.

\section{UCAPAN TERIMA KASIH}

Terima kasih kami ucapkan kepada LPPM UAJY yang telah mendukung penelitian ini.

\section{DAFTAR PUSTAKA}

[1] V. Svata, “The Quality of IS/IT: How It Can Be Assessed?,” J. Syst. Integr., 2015.

[2] A. Prasetyo and N. Mariana, "Analisis Tata Kelola Teknologi Informasi ( It Governance ) pada Bidang Akademik dengan Cobit Frame Work Studi Kasus pada Universitas Stikubank Semarang,” J. Teknol. Inf. Din., vol. 16, no. 2, pp. 139-149, 2011.

[3] ISACA, "CoBIT 4.1," IT Gov. Inst., pp. 1-29, 2007.

[4] H. Purnama and F. Samopa, "Evaluasi Tingkat Kematangan Teknologi Informasi Pada Pt Pal Indonesia (Persero) Dengan Pendekatan 
[5] S. W. Sembiring, P. Mudjihartono, and S. Rahayu, "Evaluasi Penerapan Teknologi Informasi di PT. Prudential Indonesia Menggunakan Model Cobit Framework 4.1," Semin. Nas. Inform. 2013 (semnasIF 2013), 2013.

[6] H. T. Sihotang, "Penerapan Tata Kelola Teknologi Informasi Dengan Menggunakan Cobit Framework 4.1 Studi Kasus pada PT. Perkebunan Nusantara III Medan (Persero),” J. Mantik Penusa, 2015.

[7] F. Tugas, "Assessing the Level of Information Technology (IT) Processes Performance and Capability Maturity in the Philippine Food, Beverage, and Tobacco (FBT) Industry Using the CobiT Framework," J. Manag. Inf. Decis. Sci., 2010.

[8] S. Hosseinbeig, D. Karimzadgan Moghadam, D. Vahdat, and R. Askari Moghadam, "Combination of IT strategic alignment and IT governance to evaluate strategic alignment maturity," in 2011 th International Conference on Application of Information and Communication Technologies, AICT 2011, 2011.

[9] G. A. D. Sasmita Ratih, P. Agung Bayupati, and M. Sukarsa, "Measuring the Performance of IT Management in Financial Enterprise by Using COBIT," Int. J. Inf. Eng. Electron. Bus., 2014.

[10] R. Fabac, V. Kirinic, and V. Zebic, "IT Governance in Croatian Public Administration- The Human Resources Issues," in CENTRAL EUROPEAN CONFERENCE ON INFORMATION AND INTELLIGENT SYSTEMS, 2015, 2015.

[11] ITGI, Board Briefing on IT Governance - 2nd Edition. 2003.

[12] "Towards a pooling of ITIL V3 and COBIT," Int. J. Comput. Sci. Issues, 2011.

[13] V. M. Nasution and R. Y. Rakhman, "Aplikasi Survey Kredit Berbasis Web (Studi Kasus: PT BPR Citradana Rahayu),” in Penerapan Digital Marketing dan Teknologi Informasi Dalam Bisnis Ritel, 2016, pp. 18-29.

[14] I. G. Institute, "Cobit 4.1," Gov. An Int. J. Policy Adm., 2008.

[15] N. Azizah, "AUDIT SISTEM INFORMASI MENGGUNAKAN FRAMEWORK COBIT 4.1 PADA E-LEARNING UNISNU JEPARA," Simetris J. Tek. Mesin, Elektro dan Ilmu Komput., 2017.

[16] L. M. Da Silva and J. Souza Neto, "Method for Measuring the Alignment Between Information Technology Strategic Planning and Actions of Information Technology Governance," J. Inf. Syst. Technol. Manag., 2014.

[17] S. Ramlaoui and A. Semma, "Comparative study of COBIT with other IT Governance Frameworks," Ijcsi, 2014.

[18] M. C. Machado, F. Hourneaux Junior, and F. A. Sobral, "SUSTAINABILITY IN INFORMATION TECHNOLOGY: AN ANALYSIS OF THE ASPECTS CONSIDERED IN THE MODEL COBIT,” J. Inf. Syst. Technol. Manag., 2017.

[19] C. H. Primasari, "Kematangan Keselarasan Strategis Bisnis dan TI pada Lembaga Edukasi dan Konsultasi TI," J. RESTI (Rekayasa Sist. dan Teknol. Informasi), vol. 4, no. 1, pp. 10-16, 2020.

[20] U. Vijayakumar, "Top Management Control Functions for Information Systems in Small and Medium Enterprises," Inform. Econ. J., 2009.

[21] W. H. DeLone and E. R. McLean, “The DeLone and McLean model of information systems success: A ten-year update,” in Journal of Management Information Systems, 2003.

[22] D. Sledgianowski, J. N. Luftman, and R. R. Reilly, "Development and validation of an instrument to measure maturity of IT business strategic alignment mechanisms," Inf. Resour. Manag. J., 2006.

[23] J. Luftman, “Assessing it/business alignment," Inf. Syst. Manag., 2003.

[24] J. Luftman, K. Lyytinen, and T. ben Zvi, "Enhancing the measurement of information technology (IT) business alignment and its influence on company performance," J. Inf. Technol., vol. 32, no. 1, pp. 26-46, Mar. 2017.

[25] J. Luftman, "Measure Your Business-IT Alignment," Optim. Bus. Exec. CIOs Mag., vol. 26, no. 22, pp. 1-4, 2003.

[26] F. D. Davis, "Perceived usefulness, perceived ease of use, and user acceptance of information technology," MIS Q. Manag. Inf. Syst., 1989.

[27] I. D. Lesmono and D. Erca, “Tata Kelola Teknologi Informasi Dengan Metode COBIT 4.1 (Studi Kasus : PT.IMI),” J. Kaji. Ilm., 2018.

[28] F. P. Wheeler, S. H. Chang, and R. J. Thomas, "Moving from an executive information system to everyone's information system: Lessons from a case study," J. Inf. Technol., 1993. 